\title{
Sexual abuse characteristics in Santo André, São Paulo, Brazil: from victims to aggressors, from diagnosis to treatment
}

\author{
Maria Aparecida Dix Chehab1, Laércio da Silva Paiva ${ }^{2,3}$, Francisco \\ Winter dos Santos Figueiredo ${ }^{2,3}$, Blanca Elena Guerrero Daboin ${ }^{3}$, \\ Lígia de Fátima Nóbrega Reato ${ }^{4}$, Fernando Adami ${ }^{23^{*}}$
}

${ }^{1}$ Prefeitura Municipal de Santo André. Coordenadora da Rede de Saúde para Atenção às Violências e Abuso Sexual. Faculdade de Medicina do ABC. Departamento de Pediatria. Docente da Disciplina de Hebiatria. Santo André, SP, Brasil. Av. Lauro Gomes, 2000, Vila Sacadura Cabral, CEP: 09060-870, Santo André, São Paulo, Brasil.

${ }^{2}$ Faculdade de Medicina do ABC. Laboratório de Epidemiologia e Análise de Dados, Departamento de Saúde da Coletividade. Santo André, SP, Brasil. Av. Lauro Gomes, 2000, Vila Sacadura Cabral, CEP: 09060-870, Santo André, São Paulo, Brasil.

${ }^{3}$ Faculdade de Medicina do ABC. Laboratório de Delineamento de Estudos e Escrita Científica, Departamento de Saúde da Coletividade. Santo André, SP, Brasil. Av. Lauro Gomes, 2000, Vila Sacadura Cabral, CEP: 09060-870, Santo André, São Paulo, Brasil.

${ }^{4}$ Faculdade de Medicina do ABC. Departamento de Pediatria. Professora Titular da Disciplina de Hebiatria. Santo André, SP, Brasil. Av. Lauro Gomes, 2000, Vila Sacadura Cabral, CEP: 09060870, Santo André, São Paulo, Brasil.

Manuscript received: 25 January 2017 Manuscript accepted: 12 May 2017 Version of record online: 06 September 2017

\section{Abstract}

Introduction: Sexual violence against children and adolescents in Brazil is an underreported public health problem. Knowing the profile of the victims and the factors related to each case is a strategy for the development of more effective public policies.

Objective: To describe the profile of children and adolescent victims of libidinous act, characteristics of aggression and aggressors, consequences for victims, and legal actions related to sexual abuse.

Methods: This is a descriptive study. Sociodemographic characteristics of the victims, characteristics of the aggressors and aggression, and clinical, psychological, and legal aspects of 61 sexually abused patients admitted to the specialized outpatient clinic of the Network of Health for Violence and Sexual Abuse located in Santo André, São Paulo State, Brazil, were analyzed.

Results: Victims had a mean age of 10.4 years, female $(60.7 \%, n=$ $37)$, white $(70.5 \%, n=43)$, and admitted to the care network after of 72 hours of having been a victim of abuse $(68.3 \%, n=40)$. Most of the aggressions were by a libidinous act $(65.6 \%, n=40)$ and by an individual known by the victim $(72.1 \%, n=44)$. As a result of libidinous act, the children had a change in family composition $(42.6 \%, n=26)$, cognitive disturbances $(34.4 \%, n=21)$, emotional disturbances $(83.6 \%, n=51)$, and behavioral disorders $(54.1 \%, n=$ 33). Two-thirds of the cases resulted in a police investigation, only $20 \%$ of the offenders were convicted.

Conclusion: Girls suffer sexual abuse where the perpetrator is known and close to the family; they delay seeking health services and can present mental disorders related to those abuses, but the perpetrators remain unpunished in most cases.

Keywords: libidinous act, sexual violence, children, adolescents, public health 


\section{INTRODUCTION}

Sexual violence against children and adolescents is a global public health problem, especially in low and middle income countries, where cases remain largely hidden. Less than $10 \%$ of cases reach the health system and the police due to the so-called "silence pact"1. This pact of silence is where victims of sexual assault and those responsible are aware of the violence, but for various reasons, they prefer to not to report it. This challenge becomes greater in relation to sexual and domestic violence, where it is more present and associated with feelings of fear and prejudice.

In children and adolescents, sexual violence has short- and long-term consequences for health. The victims may present physical sequelae (unwanted pregnancies, sexually transmitted diseases, and other injuries in general), psychological (cognitive, emotional, and behavioral dysfunction) $)^{2,3}$ and social (school dropout, family dysfunction, child prostitution $)^{4}$ with a higher incidence of revictimization during adolescence and/or in adulthood $^{5}$.

In recent decades, recognition of this problem and its hidden nature has resulted in intersectoral mobilization focused on early diagnosis, treatment, and prevention strategies $^{6-11}$. For example, surveillance systems and public policies have been implemented to improve information

\section{METHODS}

\section{Data source}

Data from a database collected from children and adolescents were assisted by the reference center of the Network of Health for Attention to Violence and Libidinous act (RESAVAS) from January 2008 to December 2009 were analyzed. The database was provided by RESAVAS coordinators through the authorization to carry out this research.

RESAVAS is located in the city of Santo André, which is one of 39 cities in the Metropolitan Region of São Paulo State, Brazil, with about 700,000 inhabitants. In 2010, 23\% of the population of Santo André was under 18. Its Municipal Human Development Index (IDMH) ${ }^{13}$ was 0.802 and comprises a territorial extension of $176,000 \mathrm{~km}^{2}$.

\section{Eligibility criteria}

During the study period, 160 children (under 12 years of age) and adolescents (12-18 years) were assisted in RESAVAS. They sought care services by spontaneous demand or were referred by municipal agencies, such as health centers, first aid services, hospitals, police stations, tutoring, schools, and churches for treatment and follow-up related to sexual violence and to find legal guidance.

The data considered were for 61 children and adolescents who had confirmed libidinous act and who remained in the RESAVAS during the study period and discharged (49 children did not have confirmation of libidinous act and 50 dropped out).

\section{Data collection and analyzed variables}

Information was collected from admission to RESAVAS until discharge. The information provided by quality, articulate intersectoral actions, foster networks of special attention, and social protection for victims of abuse, sexual and/or domestic violence ${ }^{12}$.

For this purpose, in 2002, the Municipality of Santo André, Southeast Brazil, implemented the Network of Health for Attention to Violence and Libidinous act (RESAVAS). RESAVAS is a multidisciplinary team whose objective is to diagnose, treat, and guide victims of abuse on social and legal aspects. It works effectively with the Department of Health, Ministry of Health, Ministry of Social Security, Department of Legal Affairs, Department of Public Security and Urban Transit, Department of Social Inclusion, Guardianship Council, Brazilian Bar Association, Children's Court and Youth and NonGovernmental Organizations.

The data collected through RESAVAS are essential to determine the magnitude and nature of violence, the profile of the victims and the aggressors in order to plan a prevention and treatment system. In this sense, the objective of this work was to describe the profile of children and adolescent victims of libidinous act, characteristics of aggressions and aggressors, consequences for victims, and legal actions related to libidinous act of cases that occurred in RESAVAS between 2008 and 2009.

the victims and/or their legal representatives was obtained by RESAVAS health professionals through a specific data collection form, with variables related to the characteristics of children and adolescents, aggressions and aggressors, the consequences of abuse for victims, and the legal aspects of every case.

Clinical evaluations were performed by RESAVAS physicians through examination of the sexual organs and the collection of material for laboratory tests. The clinical and serological segments were performed until the patient's discharge. In addition, psychological evaluations were performed by RESAVAS psychologists and, when necessary, psychiatrists.

Interpersonal interviews were conducted to evaluate the personality of the victims, and dynamics and family context. The instruments of psychological evaluation used were: projective, psychometric and expressive tests (Wechsler Intelligence Scale for Children 3rd Edition (Wisc III) ${ }^{14}$ Children's Thematic Apperception Test (CAT-A) ${ }^{15}$, HouseTree-Person test (HTP) ${ }^{15}$. Progressive Matrices of Raven ${ }^{16}$, Human Figure Drawing ${ }^{17}$ and others. The disorders identified in the evaluation were grouped into cognitive, emotional, and behavioral disorders.

The variables related to the characteristics of children and adolescents, aggressions and aggressors, the consequences of libidinous act for victims, and the legal aspects of cases are described in Figure 1.

\section{Ethical aspects}

This study was approved by the Research Ethics Committee of the Department of Health of the Municipality of Santo André, under protocol CEPSS-AS number 015/2011. 
BOARD1. Variables collected from database of RESAVAS.

\begin{tabular}{|c|c|}
\hline Characteristics & Variables \\
\hline \multirow[t]{6}{*}{ Children } & Sex \\
\hline & Age (in years) \\
\hline & Ethnicity (white, not white) \\
\hline & Sexually active before the aggression (yes, no, not applicable) \\
\hline & Institutionalized patient (yes, no) \\
\hline & Time between sexual abuse and admission (before or after 72 hours) \\
\hline \multirow[t]{4}{*}{ Aggression and/or aggressor } & Type of aggression (rape; libidinous act) \\
\hline & Numbers of aggressions (single, multiple, indeterminate) \\
\hline & Aggressor (known, unknown) \\
\hline & $\begin{array}{l}\text { Relationship of aggressor (father, brother, stepfather, uncle, grandfather, neighbor, so- } \\
\text { meone close to the family) }\end{array}$ \\
\hline \multirow[t]{5}{*}{ Consequences of abuse for children } & Changes in family composition (yes, no) \\
\hline & Pregnancy (positive, negative) \\
\hline & $\begin{array}{l}\text { Diagnosis of cognitive impairment (learning and language deficits, lack of interest in } \\
\text { studying, lack of concentration and attention) }\end{array}$ \\
\hline & $\begin{array}{l}\text { Diagnosis of emotional disturbance (fear, loss of interest in playing, shame, guilt, exa- } \\
\text { cerbation of shyness) }\end{array}$ \\
\hline & $\begin{array}{l}\text { Diagnosis of behavioral disorders (social withdrawal, running away from home, suicidal } \\
\text { and homicidal ideas, self-mutilation, sexualized behavior) }\end{array}$ \\
\hline \multirow[t]{5}{*}{ Legal consequences of abuse } & Action of guardianship council (yes, no) \\
\hline & Police report done (yes, no) \\
\hline & Children and juvenile court (yes, no) \\
\hline & Process status (not open, in progress, completed) \\
\hline & Status of offender (unpunished, convicted, other) \\
\hline
\end{tabular}

\section{RESULTS}

\section{Statistical analysis}

The descriptive analysis was performed by absolute and relative frequency of the qualitative variables and mean and standard deviation, minimum and maximum, of the quantitative variables. Data were analyzed in Stata version 11.0 (StataCorp LP, College Station, TX, USA).
The victims of libidinous act had an average age of 10.4 years $(\mathrm{SD}=4.3$, minimum 1 year and maximum 18 years), were predominantly female $(60.7 \%, \mathrm{n}=37)$, white $(70.5 \%$, $\mathrm{n}=43)$, were not institutionalized $(90,2 \%, \mathrm{n}=55)$, were not sexually active $(90.0 \%, \mathrm{n}=55)$ and were admitted to the care network after 72 hours of abuse $(68.3 \%, \mathrm{n}=41)$ (Table 1$)$.

Table 1: Characteristics of children and adolescents, victims of sexual abuse. RESAVAS, Santo André, São Paulo, Brazil, $2008-2009$.

\begin{tabular}{lcc}
\hline Characteristics of children and adolescents & $\mathbf{n}$ & $\%$ \\
\hline Sex & & 39.3 \\
Male & 24 & 60.7 \\
$\quad$ Female & 37 & 70.5 \\
Ethnicity & 43 & 29.5 \\
White & 18 & 90.2 \\
No White & 55 & 9.8 \\
Institutionalized patient & 6 & 90.0 \\
No & & 10.0 \\
Yes & 55 & 31.7 \\
Sexually active & 6 & 68.3 \\
No & & Min. - Max. \\
Yes & 19 & $1-18$ \\
Bime between sexual abuse and admission & 41 & \\
After 72 hours & Mean (SD) & 10.4 (4.3) \\
Age (in years) & & \\
\hline
\end{tabular}

SD: Standard Deviation 
Most of the aggressions were by libidinous act $(65.6 \%$, $\mathrm{n}=40)$, with one aggression $(55.7 \%, \mathrm{n}=34)$, by a known individual $(72.1 \%, \mathrm{n}=44)$, the majority was the father of the victim $(34.1 \%, \mathrm{n}=15)$ or stepfather $(18.2 \%, \mathrm{n}=8)$ (Table 2$)$.

Table 2: Characteristics of aggression and aggressor of libidinous act in children and adolescents. RESAVAS, Santo André, São Paulo, Brazil, 2008-2009.

\begin{tabular}{|c|c|c|}
\hline Characteristics of aggressor and/or aggression & $\mathbf{n}$ & $\%$ \\
\hline \multicolumn{3}{|l|}{ Type of aggression } \\
\hline Rape & 21 & 34.4 \\
\hline Libidinous act & 40 & 65.6 \\
\hline \multicolumn{3}{|l|}{ Number of aggressions } \\
\hline Single & 34 & 55.7 \\
\hline Multiple & 26 & 42.6 \\
\hline Indeterminate & 1 & 1.7 \\
\hline \multicolumn{3}{|l|}{ Aggressor } \\
\hline Known & 44 & 72.1 \\
\hline Unknown & 17 & 27.9 \\
\hline \multicolumn{3}{|l|}{ Relationship with the aggressor } \\
\hline Father & 15 & 34.1 \\
\hline Stepfather & 8 & 18.2 \\
\hline Uncle & 3 & 6.8 \\
\hline Grandfather & 4 & 9.1 \\
\hline Neighbor & 7 & 15.9 \\
\hline Someone close to the family & 6 & 14.6 \\
\hline Brother & 1 & 2.3 \\
\hline
\end{tabular}

As a consequence of having suffered libidinous act, $42.6 \%(n=26)$ of the children had altered family composition, but most children were still living close to the aggressor
(57.4\%). There were no cases of pregnancy, but $34.4 \%(\mathrm{n}=$ 21) had cognitive disturbances, $83.6 \%(n=51)$ emotional disturbances, and $54.1 \%(\mathrm{n}=33)$ behavioral disorders (Table 3$)$.

Table 3: Consequences of libidinous act in children and adolescents. RESAVAS, Santo André, São Paulo, Brazil 2008-2009.

\begin{tabular}{lcc}
\hline Characteristics & $\mathbf{n}$ & $\%$ \\
\hline Changes in family composition & 35 & 57.4 \\
No & 26 & 42.6 \\
Yes & & 100.0 \\
Pregnancy & 20 & 0.0 \\
No & 0 & 65.6 \\
Yes & 40 & 34.4 \\
Diagnosis of cognitive impairment & 21 & 16.4 \\
No & & 83.6 \\
Yes & 10 & 51 \\
Diagnosis of emotional disturbance & & \\
No & & \\
Yes & 28 & 54.9 \\
Diagnosis of behavioral disorders & 33 & 54.1 \\
Yes & & \\
\hline
\end{tabular}

The legal aspects showed that the Guardianship Council acted in $96.7 \%$ of the cases. Of the total victims, $65.6 \%$ went to the police station to file a police report and $27.9 \%$ to the Children and Youth Court. In about $40 \%$ of cases, the case against the offender had not been initiated; in the remainder, approximately $30 \%$ were completed in the period in which the victim was followed, and the others were still in progress until the patient was discharged (31\%). Of the completed cases, almost $80 \%$ of the perpetrators remained unpunished (Table 4). 
Table 4: Legal aspects of sexual abuse in children and adolescents. RESAVAS, Santo André, São Paulo, Brazil. 2008-2009.

\begin{tabular}{llc}
\hline Legal aspects of the aggression & $\mathbf{n}$ & $\%$ \\
\hline Action of guardianship council & 2 & 3.3 \\
No & 59 & 96.7 \\
Yes & & 34.4 \\
Police report done & 21 & 65.6 \\
No & 40 & 72.1 \\
Yes & & 27.9 \\
Children and juvenile court & 44 & 39.3 \\
No & 17 & 31.2 \\
Yes & & 29.5 \\
Process Status & 24 & 19 \\
Not open & 19 & 78.3 \\
Completed & 18 & 21.7 \\
Status of offender & & 48 \\
Unpunished & 13 & \\
\hline
\end{tabular}

\section{DISCUSSION}

The objective of this study was to investigate the profile of children and adolescent victims of libidinous act, the characteristics of aggressions and aggressors, the consequences for victims, and the legal actions related to libidinous act in the network of health care for violence and abuse.

It was found that victims of libidinous act had a mean age of 10.4 years and were predominantly female and white. This scenario is very similar to the Brazilian reality, where $83.2 \%$ of the victims of libidinous act against children are female and $39.5 \%$ occur in victims between 10 and 14 years of age ${ }^{18,19}$. Regarding ethnicity, the findings of the National Committee of Combating Sexual Violence against Children and Adolescents ${ }^{20}$ also report a higher incidence of libidinous act in white children and adolescents.

Unfortunately, in this study, most victims sought care for treatment after 72 hours of libidinous act (68.8\%), with a low number of victims being able to receive prophylaxis of sexually transmitted diseases (STD) due to exposure time. This is because most of the time, the abuser oppresses the victim, or tries to hide the case $\mathrm{e}^{21}$.

Two-thirds of the sexual assaults that occurred in the study population were characterized as rape. Rape is a crime under Brazilian $\mathrm{law}^{22}$, determining imprisonment from 6 to 10 years, in cases of libidinous act with perpetration and frequent physical marks. It reflects the audacity of the abuser who does not appear to be identified and confirmed as the perpetrator of libidinous act by DNA testing.

The highest proportion of offenders was individuals close to the victims, such as the father or stepfather. Thus, libidinous act of children and adolescents in Brazil is a type of domestic violence, as confirmed in Curitiba (Paraná), where $75.2 \%$ of the cases occurred in the victim's residence $^{23}$.
The fact that the victim is abused and continues to live near the offender causes mental health to be affected $^{24}$. In this study, most of the victims presented emotional, psychological, and behavioral disorders due to sexual violence, which, fortunately, can be reduced by the mental health treatment offered by RESAVAS. Possibly, the changes in mental health and in the future social adjustment of the victims are directly related to the personality characteristics, the type of violence suffered, and the capacity to react against the stress ${ }^{25}$.

The high proportion of changes in family composition found in this study also illustrates intrafamily libidinous act. The incestuous relative often "appropriates" his victim, looking through the image of a jealous and concerned caretaker who tries to be always close, leading the victim to understand the situation as a natural manifestation of affection. The child begins to express that something is wrong in his/her life when he/she is mature, acquiring more knowledge and, finally, showing moral values ${ }^{23}$.

The fact that the aggressor is an individual close to the victim and has a strong degree of kinship causes many of the cases to be masked and omitted. This omission may be accentuated by the territorial extension and existing socioeconomic inequalities, which indirectly provide barriers to health and legal services.

Despite complaints at the police station and in the police assessment of the Child and Youth Court, most offenders $(80 \%)$ went unpunished after the crime. This impunity is 13 times the estimated number of criminals punished worldwide $(6 \%)^{20}$. In addition, punishing offenders does not contribute to reducing the practice of this crime.

In Brazil, reporting libidinous act is mandatory for suspected or confirmed cases of abuse against children and adolescents, and should be reported to guardianship council, which in this study, occurred in $96.7 \%$ of the cases. 
In the remainder $(3.3 \%)$, the complaint was not reported because the victims were referred for treatment by the agency itself.

Therefore, all cases of libidinous act against children and adolescents treated by RESAVAS have been reported to the responsible authorities, as determined by law $^{26}$. However, for $39.3 \%$ of the cases, prosecution was not initiated.

Some structural modifications are necessary to change sexual violence in Brazil. The extension of the school day and the implementation of integral education (more than 7 hours) are objectives of public education policies of the federal government. Among the areas of complementary activity, the categories are "Human Rights, Citizenship and Health" and "Food and prevention".

Thus, much domestic violence, including sexual violence, could be minimized if children and adolescents remained in school full-time and obtained those guidelines already proposed by government policies. Currently, only $4.7 \%$ of Brazilians study full-time, according to data from 2009 of the National Institute of Studies and Educational Research Anísio Teixeira (INEP) ${ }^{22}$.

The victims' profile was white, 10-year-old girls who lived with the family, and were sexually assaulted by someone known and close to them, such as their father or stepfather. After suffering abuse, children remain living near the aggressor and present mental disorders such as cognitive, emotional, and behavioral disorders. As in other regions of Brazil, although legal services are present, in most cases, the accused are not tried and remain unpunished.

\section{Abbreviations}

Network of Health for Attention to Violence and Libidinous act (RESAVAS).

National Institute of Educational Studies and Research Anísio Teixeira (INEP).

\section{Conflict of Interests}

None.

\section{Contribution of authors}

MADC participated in the study design and contributed to writing and reviewing the manuscript. LSP contributed to writing and reviewing the manuscript and participated in the statistical analysis. FWSF contributed to writing and reviewing the manuscript and participated in the statistical analysis. BEGD contributed to writing and reviewing the manuscript. LFNR participated in the design of the study, and contributed to writing and reviewing the manuscript. FA participated in the design of the study, contributed to writing and revising the manuscript and participated in the statistical analysis. All authors read and approved the final version of the manuscript.

\section{REFERENCES}

1. Dias MB. Incesto: um pacto de silêncio. Rev CEJ. 2006;10(34):11-14.

2. Wingo AP, Wrenn G, Pelletier T, Gutman AR, Bradley B, Ressler KJ. Moderating effects of resilience on depression in individuals with a history of childhood abuse or trauma exposure. J Affect Disord. 2010;126(3):411-4. DOI: http://dx.doi.org/10.1016/j.jad.2010.04.009

3. Friedman MS, Marshal MP, Guadamuz TE, Wei C, Wong CF, Saewyc E, et al. A meta-analysis of disparities in childhood sexual abuse, parental physical abuse, and peer victimization among sexual minority and sexual nonminority individuals. Am J Public Health. 2011;101(8):1481-94. DOI: http://dx.doi.org/10.2105/AJPH.2009.190009

4. Ferreira JD. Estudo de fatores relacionados com a violência sexual contra crianças, adolescentes e mulheres adultas. Rev Bras Ginecol Obstet. 2000:22(7):459. DOI: http://dx.doi.org/10.1590/S0100-72032000000700011

5. Hill JM, Vernig PM, Lee JK, Brown C, Orsillo SM. The development of a brief acceptance and mindfulness-based program aimed at reducing sexual revictimization among college women with a history of childhood sexual abuse. J Clin Psychol. 2011;67(9):969-80. DOI: http://dx.doi.org/10.1002/jclp.20813

6. Heimer G, Posse B, Stenberg A, Ulmsten U. A national center for sexually abused women in Sweden. Int J Gynaecol Obstet. 1996;53(1):35-9.

7. Kassim K, Kasim MS.. Sexual abuse: psychosocial aspects of 101 cases seen in an urban Malaysian setting. Child Abuse Negl. 1995;19(7):793-9.

8. Newton-Taylor B, DeWit D, Gliksman L. Prevalence and factors associated with physical and sexual assault of female university students in Ontario. Health Care Women Int. 1998;19(2):155-64. DOI: http://dx.doi.org/10.1080/073993398246485

9. Felizardo MJA, Ribeiro DAA, Santos LES, Gradim CVC. Uma abordagem sobre a violência infantil no campo histórico, social e de saúde. Pediatr Moderna. 2011;47(2):47-52.

10. Kellogg N; American Academy of Pediatrics Committee on Child Abuse and Neglect. The evaluation of sexual abuse in children. Pediatrics. 2005;116 (2):506-12. DOI: http://dx.doi.org/10.1542/peds.2005-133

11. Njaine K, Assis SG, Constantino P. Impactos da violência na saúde. Rio de Janeiro: Sergio Arouca; 2009.

12. Thomazine AM, Toso BRGO, Viera CS. Abordagem da atenção primária à saúde na violência intrafamiliar infantil. Rev Soc Bras Enferm Ped. 2014;14(2):105-12.

13. Instituto Brasileiro de Geografia (IBGE). Censos demográficos. [cited 2016 Ouc 15] Available from: http://www.ibge. gov.br/home/estatistica/populacao/censo2010/default.shtm

14. Linhares MBM, Marturano EM, Loureiro SR, Machado VLS, Lima AS. Crianças com queixa de dificuldade escolar que procuran ajuda psicológica: avaliação intelectual através do WISC. Estudos Psicol. 1996;13(1):27-39. 
15. Silva MFX, Villemor-Amaral AE. A auto-estima no CAT-A e HTP: estudo de evidência de validade. Aval Psicol. 2006;5(2):205-15.

16. Pasquali L, Wechsler S, Bensusan E. Raven's colored progressive matrices for children: a validation study for Brazil. Aval Psicol. 2002;1(2):95-110.

17. Wecheler SM, Schelini PW. Validity of human figure drawing for children's cognitive assessment. Aval Psicol. 2002;1:29-38.

18. Waiselfisz JJ. Mapa da violência 2012: crianças e adolescentes do Brasil. Flacso; 2012.

19. Drezet J, Vasconcellos RM, Pedroso D, Blake MT, Oliveira AG, Abreu LC. Transmission of anogenital warts in children and association with sexual abuse. J Hum Growth Dev. 2012;22(1):34-40. DOI: http://dx.doi.org/10.7322/jhgd.20047

20. Fundo das Nações Unidas para a Infância (UNICEF). The State of the world's children 2006. Brasília: UNICEF; 2005.

21. Vertamatti MAF, Abreu LC, Barbosa CP. Time lapsed between sexual aggression and arrival at the Brazilian health service. J Hum Growth Dev. 2013;23(1):46-51. DOI: http://dx.doi.org/10.7322/jhgd.50390

22. Instituto Nacional de Estudos e Pesquisas Educacionais Anísio Teixeira (INEP). Ministry of Education and Culture. National Institute for Educational Studies and Research "Anísio Teixeira". Board of Education Statistics. 2009.

23. Pfeiffer L, Salvagni EP. [Current view of sexual abuse in childhood and adolescence]. J Pediatr (Rio J). 2005;81(5 Suppl.0):S197-204. DOI: http://dx.doi.org/10.1590/S0021-75572005000700010

24. Lucena KDT, Deninger LSC, Coelho HFC, Monteiro ACC, Vianna RPT, Nascimento JA. Analysis of the cycle of domestic violence against women. J Hum Growth Dev. 26(1):139-46. DOI: http://dx.doi.org/10.7322/jhgd.119238

25. Pathirana MIBD. Psychological impact of violence and abuse in the lives of street children in Sri Lanka. J Hum Growth Dev. 2000;10(2):47-59. DOI: http://dx.doi.org/10.7322/jhgd.39634

26. Brasil. Ministério da Saúde. Notificação de maus-tratos contra crianças e adolescentes pelos profissionais de saúde. Brasília: Ministério da Saúde; 2002.

\section{Resumo}

Introdução: Violência sexual contra crianças e adolescentes no Brasil é um problema de saúde pública subnotificado. Conhecer o perfil dos casos e dos fatores relacionados a estes casos é uma estratégia para o desenvolvimento de políticas públicas mais efetivas.

Objetivo: Descrever o perfil de crianças e adolescentes vítimas de abuso sexual, as características das agressões e dos agressores, as consequências para as vítimas e ações jurídicas relacionadas ao abuso sexual.

Método: Foram analisadas características sociodemográficas das vítimas, características dos agressores e agressão, bem como aspectos clínicos, psicológicos e legais, de 61 pacientes que sofreram abuso sexual admitidos no ambulatório especializado da Rede de Atenção à Saúde por Violência e Abuso Sexual, em Santo André, Brasil.

Resultados: As vítimas tinham média de idade de 10,4 anos, do sexo feminino $(60,7 \%, \mathrm{n}=37)$, de cor branca $(70,5 \%, n=43)$ e que foram admitidas na rede de atendimento depois de 72 horas de ter sofrido o abuso $(68,3 \%$, $n=40)$. A maior parte das agressões foi por ato sexual $(65,6 \%, n=40)$ e por indivíduo conhecido $(72,1 \%, n=44)$. Em consequência de ter sofrido abuso sexual, as crianças tiveram alteração da composição familiar $(42,6 \%$, $\mathrm{n}=26)$, apresentaram distúrbios cognitivos $(34,4 \%, n=21)$, distúrbios emocionais $(83,6 \%, n=51)$ e distúrbios comportamentais $(54,1 \%, n=33)$. Dois terços dos casos resultaram em investigação policial, apenas $20 \%$ dos criminosos foram condenados.

Conclusão: Meninas sofrem atos sexuais onde o agressor é conhecido e próximo, demoram a procurar os serviços de saúde e apresentam distúrbios mentais relacionados a esses abusos, mas os agressores continuam impunes na maior parte dos casos.

Palavras-chave: abuso sexual, violência sexual, crianças, adolescentes, saúde pública

- The authors, this article is distributed under the terms of the Creative Commons Attribution 4.0 International License (http:// creativecommons.org/licenses/by/4.0/), which permits unrestricted use, distribution, and reproduction in any medium, provided you give appropriate credit to the original author(s) and the source, provide a link to the Creative Commons license, and indicate if changes were made. The Creative Commons Public Domain Dedication waiver (http://creativecommons.org/publicdomain/zero/ $1.0 /)$ applies to the data made available in this article, unless otherwise stated. 